\title{
Improving patient care trajectories: an innovative quasi-experimental research method for health services
}

\author{
Melhoria da linha de cuidado do paciente: um método de pesquisa \\ quase-experimental inovador para serviços de saúde
}

Eneida Rached Campos ${ }^{1}$

Djalma de Carvalho Moreira-Filho ${ }^{1}$

Marcos Tadeu Nolasco da Silva ${ }^{1}$

${ }^{1}$ Faculdade de Ciências Médicas, Universidade Estadual de Campinas. R. Tessália Vieira de Camargo, Cidade Universitária. 13083-887 Campinas SP Brasil. eneida@fcm.unicamp.br

\begin{abstract}
Scores to predict treatment outcomes have earned a well-deserved place in healthcare practice. However, when used to help achieve excellence in the care of a given disease, scores should also take into account organizational and social aspects. This article aims to create scores to obtain key variables and its application in the management of care of a given disease. We present a method called Epidemiological Planning for Patient Care Trajectory (PELC) and its application in a research of HIV pediatric patients. This case study is presented by means of two studies. The first study deals with the development of the method PELC. The second is HIV Pediatric case-control study based on PELC method. HIV pediatric research - the first practical PELC application - found these four key variables to the individual quality level care trajectories: adherence to $A R T$, attending at least one appointment with the otolaryngologist, attending at least one appointment with social services, and having missed one or more routine appointments. We believe PELC method can be used in researches about any kind of care trajectories, contributing to quality level advancements in health services, with emphasis on patient safety and equity in healthcare.

Key words Health services research, Health planning guidelines, Quality improvement, Checklist
\end{abstract}

Resumo O uso de escores preditores ganhou merecido espaço nas práticas de saúde. Todavia, quando usados para alcançar a excelência do cuidado, os escores devem levar em conta também aspectos organizacionais e sociais. O objetivo deste artigo é criar escores para obter variáveis-chaves e sua aplicação na gestão do cuidado de uma determinada doença. Apresentamos um método chamado Planejamento Epidemiológico de Linha de Cuidado (PELC) e sua aplicação em pesquisa com pacientes HIV pediátricos. Este estudo de caso é apresentado por meio de dois estudos. O primeiro, sobre o desenvolvimento do método PELC. O segundo é um estudo de caso-controle em pacientes pediátricos com HIV, realizado com base no método PELC. A pesquisa HIV Pediátrico - primeira aplicação do método PELC - encontrou 4 variáveis chaves para o grau de qualidade da trajetoria de cuidado do paciente: aderência ao antirretroviral; ter pelo menos uma consulta no otorrinolaringologista; ter pelo menos uma consulta com assistente social; e ter faltado uma ou mais vezes a consulta de rotina. Acreditamos que o PELC pode ser aplicado em qualquer tipo de linha de cuidado, contribuindo para avanços na qualidade dos serviços de saúde, com ênfase na segurança do paciente e na equidade.

Palavras-chave Pesquisa sobre serviço de saúde, Diretrizes para o planejamento em saúde, Melhoria da qualidade, Lista de verificação 


\section{Introduction}

Health services, based on the disease care guidelines, provide clinical, organizational and social actions to deliver healthcare to each patient, striving to ensure access, resolution, completeness and rational use of resources.

A core value of an individual care trajectory is to heal without faults such as errors or nonconformities in daily practice, delays in patient flow, lack of resources, and low patient adherence. These and other faults may cause health harms and death ${ }^{1,2}$.

One of the vital issues for improving the individual care trajectory is the establishment of new systems that would measure and close existing gaps $^{3,4}$. We have not found in the literature any methodology to create such systems, which, in addition to clinical factors, also contemplates organizational and social factors often included in the care guidelines of many diseases such as HIV, cancer and others.

To test and determine the best care trajectory and to ensure its quality, we created the method of Epidemiological Planning for Patient Care Trajectory - PELC (from the original name in Portuguese: Planejamento Epidemiológico de Linha de Cuidado $\left.{ }^{5,6}\right)$. This study was approved by the Research Ethics Committee of the School of Medical Sciences, University of Campinas, SP, Brazil.

The PELC method aimed to develop and improve the individual care trajectory.

This paper aimed to present the PELC method and the first research carried out using this method - HIV pediatric research.

This case study is based on the PELC method (first study) and its first application (second study). The first study deals with the development of the PELC method - presents a procedure to plan and carry out a PELC research (Figure 1) and steps of the procedure were illustrated using the HIV pediatric research. The second study presents the HIV pediatric research.

\section{PELC research method}

The theoretical study that created PELC was centered on the establishment of links between quasi-experimental studies ${ }^{7-9}$ and managerial issues $^{10}$.

PELC researches are designed to answer three questions on the quality of the individual care trajectory: (1) What are the key variables to the quality level?; (2) Are the interventions contrib- uting to raise the quality level?; and (3) How will we know when we have reached the established quality goal?

It is also possible to perform a research to answer only the first question, in which case the research is no longer interventionist, but just observational, as our HIV pediatric research.

\section{PELC elements}

PELC has the following eight elements: (1) team of referees, (2) care quality standard instrument, (3) PELC scores, (4) standard-tracer-case, (5) group comparabitity, (6) experiment management plan, (7) aftercare system, and (8) self-reported health (PELC-self score).

A research based on PELC can be performed in one or two phases. The first phase - pretest performs observational epidemiological studies to investigate organizational, social, and clinical factors associated with outcomes based on PELC scores. In the second phase - posttest, these factors are the basis to formulate intervention hypotheses that will be tested.

The first phase has five elements: team of referees, care quality standard instrument, PELC scores, standard-tracer-case, group comparabitity. The second phase adds two elements: experiment management plan and aftercare system. The self-reported health element is optional score and may be used in both parts.

\section{Design of a research based on PELC method}

Because an experimental design would not be feasible to investigate individual care trajectory, a quasi-experimental approach was chosen to be used in a PELC research. Since quasi-experimental studies have important limitations, the reader may wish to refer to the literature ${ }^{8}$ for further discussion.

PELC elements come up in different steps of the procedure (Figure 1) that describes a PELC research.

For the study population (Figure 1, step 1), patients are selected according to inclusion and exclusion criteria.

The second step of a PELC research is assembling a team of referees made up by experts in the disease and, if it is necessary, by epidemiologists (Figure 1, step 2). The team of referees performs two tasks described below (Figure 1, steps 3-5): defining the care quality standard, and building the care quality standard instrument. 


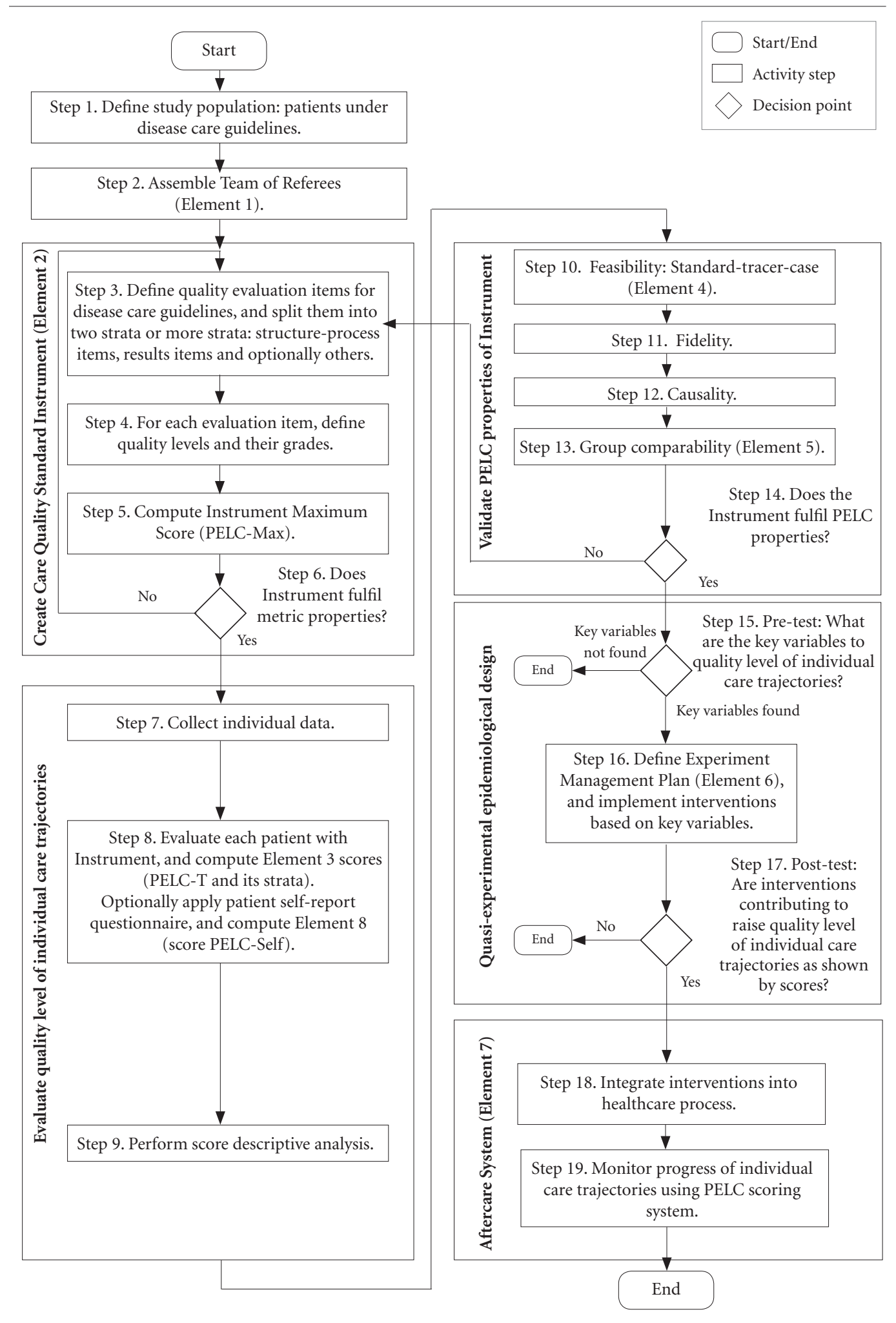

Figure 1. PELC ${ }^{*}$ research steps and elements

* PELC - Method of Epidemiological Planning for Care Trajectory Improvement 


\section{Care quality standard instrument}

The way we found to implement quality management in individual care trajectories is to ask the team of referees to select a manageable set of evaluation items. We called this set the 'care quality standard'. It formalizes the quality goal referred in the third question of PELC researches. The construction of the care quality standard draws upon five sources: treatment of the quasi-experimental study $^{8}$, quality improvement ${ }^{10}$, technology ${ }^{11}$, the WHO World Alliance for Patient Safety ${ }^{12}$, and Donabedian's triad structure-process-results ${ }^{13}$.

Each evaluation item must be relevant, observable and numerically measurable. There must be at least two strata of evaluation items (Figure 1, step 3): structure-process items (resources and actions) on one hand and results items (therapeutic success) on the other one.

For each evaluation item, the team of referees establishes criteria defining different numerical grades, which represent how well the requirement has been fulfilled (Figure 1, step 4). Thus, a minor item may be given grades from 0 to 1 , and a major one, from 0 to 17 . The maximum score (PELC-Max) is the sum of the highest possible grades of all evaluation items (Figure 1, step 5), representing the maximum possible quality level of a patient trajectory in the research.

As an evaluation instrument, the care quality standard instrument must have its metric properties verified by validity and reliability tests such as content validity, construct validity, criterion validity, etc. (Figure 1, step 6). The reader can refer to the literature for details ${ }^{14}$. In addition, the care quality standard instrument must have all four PELC properties verified: feasibility, fidelity, causality, and group comparability (Figure 1 steps 10-14 described below). If the instrument fails any validation test, it must be reviewed by the team of referees (Figure 1, step 14).

Each PELC research either creates its own care quality standard instrument or uses one instrument created by a previous PELC research.

The care quality standard instrument consists in a sheet, similar to a questionnaire or a checklist $^{3}$, to be filled out by a data collector of the research team for each patient of the study population. A simplified version of the instrument of the HIV pediatric research is shown in Figure 2. This instrument is a practical means to measure how well the care actually received by an individual patient approximates the care quality standard established for the study. It attempts to encapsulate, to the extent possible, the whole situation of a patient into a single number: the individual's care trajectory score. The individual patient score is the total of grades.

\section{Evaluation of the patient care trajectory (PELC-T score)}

The evaluation of the patient care trajectory is illustrated on Figure 1 steps 7 - 9.

The data sources may be medical records, hospital information systems, or others (Figure 1, step 7). Data are collected from patient care trajectories over a predetermined period of investigation. For example, in the HIV pediatric research, we retrospectively evaluated 2 years of individual care trajectories.

Each patient care trajectory is measured by the care quality standard instrument. The sum of grades of all evaluation items is his/her care trajectory score, or PELC-T score (Figure 1, step $8)$. It can vary from zero to PELC-Max (Table 1).

The letter $\mathrm{T}$ stands for total, as a reminder that the PELC-T score can be divided into two or more partial scores, according to strata, as defined by the researcher. In this presentation of the PELC method, we assume a simple score composed of two strata: one representing the individual structure-process conformity degree (PELC$\mathrm{SP}$ ), and the other representing the individual result conformity degree (PELC-Res).

After calculating PELC-T and its components PELC-SP and PELC-Res for all patients a descriptive analysis is performed (Figure 1, step 9).

\section{Validate PELC properties of instrument}

After computing care trajectory scores for all individuals, the care quality standard treatment instrument is validated with regard to all four PELC properties (Figure 1, steps 10-14). Each validation is described below.

Feasibility - Aiming to make sure that the goals envisioned by the team of referees (the maximum score) are in fact achievable, at least one standard-tracer-case must be found in the population. A standard-tracer-case is any patient having his/her care trajectory score (PELC-T) closely approaching the goal of PELC-Max (Figure 1, step 10). How closely it must approaches the goal is left to the judgment of the team of referees. For example, in the HIV pediatric research, one patient received a PELC-T score of 97 out of a PELC-Max of 100 points, which was regarded as a very high score. Thus, this patient is a standard-tracer-case. 


\begin{tabular}{|c|c|c|c|}
\hline \multicolumn{4}{|c|}{ Evaluations are based on records of routine appointments over the period } \\
\hline & Item & Criteria & Grades \\
\hline \multirow{18}{*}{ 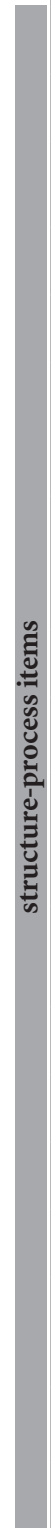 } & 1. Patient growth & $\begin{array}{l}\text { Recorded in } 80 \% \text { of appointments } \\
\text { Otherwise }\end{array}$ & $\begin{array}{l}2 \\
0\end{array}$ \\
\hline & 2. Patient feeding & $\begin{array}{l}\text { Recorded in } 80 \% \text { of appointments } \\
\text { Otherwise }\end{array}$ & $\begin{array}{l}1 \\
0\end{array}$ \\
\hline & $\begin{array}{r}\text { 3. Time spent in different } \\
\text { locations }\end{array}$ & $\begin{array}{l}\text { At least one record each year of time spent at home, daycare, school, work } \\
\text { Otherwise }\end{array}$ & $\begin{array}{l}2 \\
0\end{array}$ \\
\hline & 4. Family life notes & $\begin{array}{l}\text { Recorded at least once a year } \\
\text { Otherwise }\end{array}$ & $\begin{array}{l}2 \\
0\end{array}$ \\
\hline & 5. Social and affective life & $\begin{array}{l}\text { Steep, mood, discipline, friendships recorded at least once annually } \\
\text { Otherwise }\end{array}$ & $\begin{array}{l}1 \\
0\end{array}$ \\
\hline & 6. Sex life & $\begin{array}{l}\text { Patient under age } 12 \\
\text { Patient age } 12 \text { and above: if at least twice annually doctor provided sexual } \\
\text { guidance and for female patients referred to gynecologist } \\
\text { Otherwise }\end{array}$ & $\begin{array}{l}2 \\
2 \\
0\end{array}$ \\
\hline & 7. Sexual development & $\begin{array}{l}\text { Patient under age } 10 \\
\text { Patient age } 10 \text { or above, and at least one Tanner staging annually till stage } \\
5 \text { reached } \\
\text { Otherwise }\end{array}$ & $\begin{array}{l}2 \\
2 \\
0\end{array}$ \\
\hline & 8. HIV diagnostic & $\begin{array}{l}\text { Test sequence done as per recommendations from health authorities } \\
\text { Otherwise }\end{array}$ & $\begin{array}{l}5 \\
0\end{array}$ \\
\hline & $\begin{array}{l}\text { 9. Interval between routine } \\
\text { medical appointments }\end{array}$ & $\begin{array}{l}\text { Intervals as per recommendations from health authorities } \\
\text { Otherwise }\end{array}$ & $\begin{array}{l}5 \\
0\end{array}$ \\
\hline & $\begin{array}{r}\text { 10. Interdisciplinary } \\
\text { consultation for syphilis and } \\
\text { toxoplasmosis }\end{array}$ & $\begin{array}{l}\text { Patient not infected } \\
\text { Patient infected, and consultations with ophthalmologist, otolaryngologist } \\
\text { and neurologist done as per recommendations from health authorities } \\
\text { Otherwise }\end{array}$ & $\begin{array}{l}1 \\
1 \\
0\end{array}$ \\
\hline & $\begin{array}{r}\text { 11. Gradual disclosure of } \\
\text { diagnosis }\end{array}$ & $\begin{array}{l}\text { Patient under age } 10 \\
\text { Patient age } 10 \text { or above: if disclosure process has been recorded } \\
\text { Otherwise }\end{array}$ & $\begin{array}{l}5 \\
5 \\
0\end{array}$ \\
\hline & 12. Adherence to ART & $\begin{array}{l}\text { Two or less consultations recording lack of adherence } \\
\text { Three or more consultations recording lack of adherence }\end{array}$ & $\begin{array}{l}5 \\
0\end{array}$ \\
\hline & 13. Immunizations & $\begin{array}{l}\text { Immunization monitored annually and no dosis reported missed } \\
\text { Otherwise }\end{array}$ & $\begin{array}{l}2 \\
0\end{array}$ \\
\hline & 14. ART initiation & $\begin{array}{l}\text { Initiated as per recommendations from health authorities } \\
\text { Otherwise }\end{array}$ & $\begin{array}{l}3 \\
0\end{array}$ \\
\hline & 15. ART regimen & $\begin{array}{l}\text { Regimen as per recommendations from health authorities } \\
\text { Otherwise }\end{array}$ & $\begin{array}{l}3 \\
0\end{array}$ \\
\hline & $\begin{array}{r}\text { 16. Intervals between } \\
\text { haematological and } \\
\text { biochemical analysis }\end{array}$ & $\begin{array}{l}\text { Intervals as per recommendations from health authorities } \\
\text { Otherwise }\end{array}$ & $\begin{array}{l}3 \\
0\end{array}$ \\
\hline & $\begin{array}{l}\text { 17. Intervals between viral } \\
\text { replication analysis }\end{array}$ & $\begin{array}{l}\text { Intervals as per recommendations from health authorities } \\
\text { Otherwise }\end{array}$ & $\begin{array}{l}4 \\
0\end{array}$ \\
\hline & 18. Serological tests & $\begin{array}{l}\text { Tests performed as per recommendations from health authorities } \\
\text { Otherwise }\end{array}$ & $\begin{array}{l}1 \\
0\end{array}$ \\
\hline \multirow{3}{*}{ 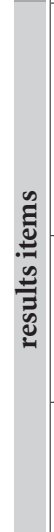 } & 19. Clinical control & $\begin{array}{l}\text { Asymptomatic patient } \\
\text { After } 4 \text { weeks of ART, if patient remained in same CDC clinical category } \\
\text { After } 4 \text { weeks of ART, if worsened once in CDC } \\
\text { After } 4 \text { weeks of ART, if worsened } 2 \text { or more times in CDC } \\
\text { If patient has been hospitalized } \\
\text { If patient is in CDC category C and developed opportunistic disease } \\
\text { If died }\end{array}$ & $\begin{array}{r}17 \\
13 \\
9 \\
5 \\
2 \\
2 \\
0\end{array}$ \\
\hline & 20. Immune control & $\begin{array}{l}\text { CD4/CD8 remained } \geq 0.8 \text { throughout the period } \\
C D 4 / C D 8 \text { initially } \geq 0.8 \text {, then dropped below, and later recovered } \\
C D 4 / C D 8 \text { initially }<0.8 \text {, then raised and remained } \geq 0.8 \\
C D 4 / C D 8 \text { initially } \geq 0.8 \text {, then dropped and remained }<0.8 \\
C D 4 / C D 8 \text { remained }<0.8, \text { throughout the period }\end{array}$ & $\begin{array}{r}17 \\
13 \\
9 \\
4 \\
0\end{array}$ \\
\hline & 21. Viral load control & $\begin{array}{l}\text { Viral load undetectable throughout the period } \\
\text { Undetectability achieved during the period and sustained } \\
\text { Undetectability achieved during the period but not sustained } \\
\text { Undetectability not achieved }\end{array}$ & $\begin{array}{r}17 \\
13 \\
9 \\
0\end{array}$ \\
\hline
\end{tabular}

Figure 2. HIV Pediatric Care Quality Standard Instrument: items and grades*.

* This is a simplified version of the Care Quality Standard Instrument of the HIV Pediatric Research. A real instrument requires more detailed criteria for assigning grades. 
Fidelity - Physicians must feel that scores effectively reflect the quality level of the care experienced by patients. During validation, individual scores are shown to the doctor in charge, who gives a yes/no answer as to whether he/she agrees with the evaluation. If doctors agree in $80 \%$ or more of the cases, this property is considered validated (Figure 1, step 11).

Causality - Evaluation items representing quality of results (outcomes), such as years of survival, should be correlated to (be a consequence of) items representing quality of structure-process, such as adherence to the prescribed treatment (Figure 1, step 12). This can be ascertained by an odds table where exposure (research and actions) is encapsulated in PELC-SP score and outcomes (therapeutic results) in PELC-Res score. Based on a descriptive analysis of each of these scores, cutoff points can be defined to split patients into the four groups of the odds table (Table 2).

Group comparability - A PELC research needs to determine outcomes (PELC scores) and then classify patients into a control group (desired outcome) and a case group (undesired outcome) for epidemiological studies (Figure 1, step 13). Many outcomes of interest could be defined; however, three of them are possible in any research: PELC-T, PELC-Res and PELC-Self (Figure 1, step 8). The definition of cutoff points for PELC scores splits patients into two groups to be compared. The cuttoff points can be set arbitrarily by the team of referees or by using an accurate statistical tool like the ROC curve (receiver operating characteristic).

The PELC-Self score is an optional outcome. It is the degree of health as self-reported by the patient in questionnaires, such as WHOQOL, SF$36^{15}$, using cross-sectional studies. The PELC-Self score is used in the PELC element called self-reported health, which studies the relationship between a patient perception of care (PELC-Self) and measures of quality level such as PELC-T and PELC-Res. This element is proposed because the quality of life as perceived by the patient is a measure to evaluate treatment outcome.

Table 1. Scores PELC descriptive analysis of the study population.

\begin{tabular}{lccc}
\hline & $\begin{array}{c}\text { PELC-T } \\
\text { (Total items of the } \\
\text { instrument) }\end{array}$ & $\begin{array}{c}\text { PELC-SP } \\
\text { (Only the structure-process } \\
\text { items of the instrument) }\end{array}$ & $\begin{array}{c}\text { PELC-Res } \\
\text { (Only the result items } \\
\text { of the instrument) }\end{array}$ \\
\hline Minimum & 23.75 & 11.00 & 0 \\
$1^{\text {st }}$ quartile & 47.12 & 28.00 & 14.75 \\
Median & 64.00 & 34.00 & 26.50 \\
Mean & 61.60 & 33.55 & 28.04 \\
Mode & 53.50 & 43.00 & 12.75 \\
$3^{\text {rd }}$ quartile & 75.00 & 39.00 & 38.25 \\
Maximum & 97.00 & 49.00 & 51.00 \\
Standard deviation & 17.94 & 7.56 & 14.30 \\
Maximum possible quality & 100 & 49 & 51 \\
level in the research & & & \\
\hline
\end{tabular}

Table 2. Conformity degree of individual HIV pediatric care trajectories: association of exposure (structureprocess score - PELC-SP) and outcomes (results score - PELC-Res).

\begin{tabular}{|c|c|c|c|c|c|c|c|c|c|}
\hline \multirow[b]{3}{*}{ PELC-SP } & \multirow{2}{*}{\multicolumn{2}{|c|}{$\begin{array}{c}\text { Cases } \\
\text { PELC-Res }<20\end{array}$}} & \multirow{2}{*}{\multicolumn{2}{|c|}{$\begin{array}{c}\text { Controls } \\
\text { PELC-Res } \geq 20\end{array}$}} & \multirow{2}{*}{\multicolumn{2}{|c|}{ Total }} & \multirow{3}{*}{ OR } & \multirow{3}{*}{ IC 95\% } & \multirow{3}{*}{$p$} \\
\hline & & & & & & & & & \\
\hline & $\mathrm{n}=54$ & $\%$ & $\mathrm{n}=112$ & $\%$ & $\mathrm{n}=166$ & $\%$ & & & \\
\hline$<30$ & 26 & 48.15 & 29 & 25.89 & 55 & 33.13 & 2.66 & $1.3-5.3$ & 0.0049 \\
\hline$\geq 30$ & 28 & 51.85 & 83 & 74.11 & 111 & 66.87 & & & \\
\hline
\end{tabular}


pretest and posttest. The period between the two phases should be long enough to allow interventions to produce their expected effects on individual care trajectories. Crossover is also possible in PELC.

Differently from most researches, the PELC method does not require a hypothesis at the beginning. The method pretest phase, which is observational and aims to find epidemiological evidences that help the formulation of hypotheses - interventions to improve the patient care trajectory; the posttest phase, which is interventionist and tests the interventions on the assistance course, will confirm or refute the hypothesis.

\section{Pretest phase}

In the pretest phase (Figure 1, step 15), the question to be answered is the first of the three PELC questions, which we can now rephrase as "What are the key variables that predict the values of the scores PELC-T, PELC-Res, PELC-Self or additional scores representing other outcomes?"

The pretest phase is explained here by a case-control design with groups. Two or more epidemiological studies with a case-control design can be used in the same PELC research. Each of these studies seeks those clinical, social, organizational factors most decisive for the outcomes represented by PELC scores. The second topic - HIV Pediatric Research - illustrated the pretest phase.

\section{Posttest phase}

The posttest phase is performed to answer the second question: "Are the interventions contributing to raise the quality level?" Interventions are made, based on the key variables found in the pretest phase, as an attempt to close the gap between the individual care trajectories and the care quality standard.

This set of interventions is what we called the experiment management plan - PELC's sixth element (Figure 1, step 16). This may involve the introduction of checklists, the establishment of pacts among the involved parties (hospital, doctors, and laboratories), educational actions about the care quality standard, nonconformity alert

systems, etc. These are predominantly management actions, as distinct from clinical actions, hence the name experiment management plan.

Interventions are regarded as a success when individual PELC scores are higher in the posttest than in the pretest (Figure 1, step 17).

\section{Aftercare system}

The aftercare system is a nonconformity prevention system comprising two elements: (1) Integrating interventions into the healthcare process (Figure 1, step 18), and (2) Monitoring progress of individual care trajectories using the PELC scoring system (Figure 1, step 19). The effective interventions - those shown to result in improvements - are integrated into the healthcare process after the end of the PELC research. The aftercare system monitoring is performed to answer the third question, now rephrased as "How will we know when we have reached the goal of the care quality standard?"

Even in cases where for some reason the experiment management plan and the aftercare system cannot be implemented, the research still has a value, as it can be regarded an educational intervention that increases awareness of a set of requirements that should be monitored.

\section{HIV Pediatric research}

This topic describes the HIV pediatric research carried out using the PELC method.

Some factors led us to choose the study population to be the children and adolescents infected with the HIV virus followed up at a university hospital as first application of the PELC method.

There are recommendations for pediatric HIV care published by the Brazilian Health Ministry (MOH-HIV guidelines $\left.{ }^{16}\right)$. In the Department of Pediatrics of the university hospital, a team of professors coordinates care and some of them collaborate in the preparation of recommendations. In addition, health professionals of the department have bond with the child and family, with a small loss of follow-up.

Advances in AIDS prevention and treatment in Brazil are admirable ${ }^{17}$. However, important issues remain to be resolved, especially concerning social, operational and regional inequalities in coverage and quality of care, and epidemiological surveillance in different regions of the country. Recent studies identified barriers to successful assistance and the impacts of culturally appropriate interventions to overcome them ${ }^{2,17}$. 


\section{Objectives of HIV pediatric research}

The objectives of the HIV pediatric research were to create an instrument to measure the quality of each patient care trajectory, aiming to identify clinical, social and organizational factors associated with the degree of quality, and then to plan future interventions based on these key factors to reach better outcomes for patients.

\section{Methods and patients}

Based on the pretest phase of the PELC method, an observational and analytical case-control study was started in July 2010 in a cohort of HIV pediatric patients from a single center.

The study population had 181 patients followed up at the Pediatric Immunodeficiency Service of the University of Campinas Teaching Hospital (SIP-HC-Unicamp), the specialized care service for children and adolescents infected with HIV in the Campinas region, with approximately 6 million inhabitants (Southeastern Brazil).

The study comprised 166 patients. The patient care trajectory was investigated in a defined period, according to the following criteria: be followed during the period defined, going back no more than three years from 31/08/2010, and this period was equal or greater than six months. The patient had to be diagnosed with HIV infection proved by laboratory tests. The patient had to be followed using the routine care service. The study excluded 15 patients: four for participating in clinical studies (for having a different routine care service); five for having evaluation period less than six months and six for not having attended in the period defined.

The survey data were collected from medical records, hospital information system, notifiable diseases information system, the logistics management system of medicines and the departmental basis of SIP-HC-Unicamp.

The following five elements of the PELC method were used in the HIV pediatric research: team of referees, care quality standard instrument, PELC scores (PELC-T, PELC-SP, PELCRes), standard-tracer-case, group comparability.

The team of referees was formed by the pediatric specialist and coordinator of the SIP-HCUnicamp and by the PELC method author - a professional of quality management and epidemiology. The pediatric specialist collaborated in the preparation of $\mathrm{MOH}-\mathrm{HIV}$ guidelines as an advisory board member. The team of referees defined the research variables.
In August 2010, the care quality standard instrument (Figure 2) was constructed by the team of referees, drawing upon three sources: pediatric care elements, MOH-HIV guidelines, and Donabedian's triad structure-process-result.

Based on Donabedian's triad ${ }^{13}$, the care quality standard included 21 highly desirable structure-process-result items to be observed in patient care trajectories. The care quality standard instrument (Figure 1, step 3) was constructed with these 21 items and its simplified version is shown in Figure 2. Among these 21 items, 18 are about structure-process (items 1-18) and 3 items are about therapeutic result (items 19-21). Furthermore, items 1-7 refer to pediatric care elements and items 8-21 refer to MOH-HIV guidelines.

Arbitrarily, for each evaluation item, the team of referees established criteria defining different numerical grades representing how well the requirement has been fulfilled (Figure 1, step 4). The sum of maximum weights of each requirement resulted in the PELC-Max score equal to 100 points - the maximum possible quality level of a patient trajectory in the research (Figure 1, step 5).

Ideally, the care quality standard instrument should be validated by both methods: the traditional validation methods (Figure 1, step 6) and the PELC method (Figure 1, step 10-14). However, the HIV pediatric care quality standard instrument was validated only for PELC method.

The evaluation period of each patient care trajectory was set in October 2010, lasting approximately two years: mean $2.09( \pm 0.25)$; minimum 0.67 and maximum 2.91 .

Under the supervision of the pediatric specialist, a single evaluator collected data and calculated the scores of 166 patients. Each patient care trajectory was measured using the care quality standard instrument (Figure 2). Each patient received a PELC-T score value (Figure 1, step 7-8).

After perform the score descriptive analysis (Table 1), the instrument was validated with regard to all four PELC properties (Figure 1, steps 10-14): feasibility, fidelity, causality and group comparability.

Feasibility was validated because there was a standard-tracer-case: one patient received PELC-T score of 97 out of a PELC-Max of 100 points. Fidelity was validated because the pediatricians felt that scores effectively reflected the quality level of care experienced by patients.

To test causality, we assemble the odds table. The PELC-T score was broken into two parts: PELC-SP representing the exposure level (the 
sum of grades of structure-process items) and PELC-Res representing the outcomes (the sum of grades of result items). The cutoff points 20 to PELC-Res and 30 to PELC-SP were defined by the team of referees based on the first quartile. Table 2 had been built and these values demonstrated that the structure-process items are in fact correlated to the result items, thus validating the property of causality: there was a 2.66 times higher risk of a patient with PELC-SP $<30$ - unsatisfactory degree of structure-process items - to achieve PELC-Res $<20$ - unsatisfactory degree of result items $(\mathrm{OR}=2.66$; $\mathrm{CI} 95 \%=1.35-5.28 ; \mathrm{p}=$ 0.0049).

The HIV pediatric research defined two outcomes: PELC-T (total items of the instrument) and PELC-Res (only the result items of the instrument). Thus, the research carried out two case-control studies: PELC-Res study and PELC-T study. HIV pediatric patients were classified into control group (desired score PELC) and case group (undesired score PELC) for each one of the studies.

In the PELC-T study, the team of referees selected PELC-T score as the outcome with a cutoff point equal to 75 , based on the third quartile, resulting in a case group of 122 patients and a control group of 44 patients.

In the PELC-Res study, the team of referees selected PELC-Res score as the outcome with a cutoff point equal to 20, based on the first quartile, resulting in a case group of 54 patients and a control group of 112 .

The instrument fulfilled all the four PELC properties.

The collected data were tabulated in Excel $^{\circledR}$ for Windows version 2007 (Microsoft, Redmond, WA, USA). Statistical analysis was performed with the " $R$ " version 2.12.1. The collected data were adjusted using the logistic regression model, having as outcomes the PELC-Res score in the first case-control and the PELC-T score in the second study. "Odds ratio" (OR) and 95\% confidence intervals (95\% CI) were obtained for the studied factors. $\mathrm{P}$ values $<0.05$ were considered significant in hypothesis tests.

HIV pediatric research based on case-control epidemiological approaches answered the question (Figure 1, step 15): "What are the key variables that predict the values of PELC-T and PELC-Res scores?" The two case control studies found the four key factors described below.

\section{HIV pediatric research results}

The study comprised 166 patient care trajectories. The general characteristics of the study population are shown in Table 3.

The results of the quality grade of patient care trajectories based on the instrument were (Table 1): PELC-T score (the maximum possible score PELC-T equal to 100 points) value ranged from $24 \leq$ PELC-T $\leq 97$, mean 61.60 ( \pm 17.94$)$, median 64, mode 53.50. The two strata of PELC-T score: PELC-Res score (the maximum possible score PELC-Res equal to 51 points) value ranged from $0 \leq$ PELC-Res $\leq 51$, mean 28.04 ( \pm 14.30), median 26.50, mode 12.75, and PELC-SP score (the maximum possible score PELC-SP equal to 49 points) value ranged from $11 \leq \mathrm{PELC}-\mathrm{SP} \leq 49$, mean 33.55 ( \pm 7.56$)$, median 34 , mode 43 .

The HIV pediatric research found four key variables. The study with PELC-Res as outcome found two key variables: adherence to ART (OR $=0.26$; CI95\% $=0.09-0.69 ; \mathrm{p}=0.007)$, and attending at least one appointment with the otolaryngologist $(\mathrm{OR}=3.9 ;$ CI95\% $=1.27-12.51 ; \mathrm{p}$ $=0.018$ ). The study having PELC-T as outcome found two additional key variables: attending at least one appointment with social services (OR = 6.36; CI95\% $=1.53-44.36 ; \mathrm{p}=0.024)$, and having missed one or more routine appointments $(\mathrm{OR}=$ 13.01; CI95\% $=3.42-86.81 ; \mathrm{p}=0.001$ ).

\section{Discussion}

Our study adds to the existing knowledge the possibility of using pretest and posttest quasi-experimental studies with an innovative method to find key variables associated with the quality level of individual care trajectories. This level is evaluated with a specifically developed care quality standard instrument. The HIV pediatric research proposed a new instrument to measure the degree quality of the HIV pediatric patient care trajectory based on a standard of systemic scope, consisting of clinical, organizational and social factors.

Thus, the PELC-T score of each patient of a cohort contrasts with other scores used for estimating the mortality risk and other major endpoints in clinical practice, such as the APACHE (acute physiology and chronic health evaluation $)^{18}$, because, in addition to clinical and physiological aspects which these are based on, PELC also contemplates organizational and social factors. 
Table 3. Characteristics of the study population.

\begin{tabular}{|c|c|}
\hline Characteristic & Values \\
\hline Gender & $88(53 \%)$ male; $78(47 \%)$ female \\
\hline Age at the beginning of evaluation period & $124(75 \%)<13$ years; $42(25 \%) \geq 13$ years \\
\hline Social need level ${ }^{\#}$ & $\begin{array}{l}111(67 \%) \text { lower; } \\
45(27 \%) \text { middle; } \\
10(6 \%) \quad \text { high; }\end{array}$ \\
\hline $\begin{array}{l}\mathrm{CDC}^{\mathfrak{E}} \text { - clinical staging } \\
\text { at the end of the evaluation period }\end{array}$ & $\begin{array}{l}121(73 \%) \text { clinical staging N,A,B } \\
45(27 \%) \quad \text { clinical staging C }\end{array}$ \\
\hline $\begin{array}{l}\mathrm{CDC}^{\varepsilon} \text { - immunological category } \\
\text { at the end of the evaluation period }\end{array}$ & $\begin{array}{l}29(18 \%) \text { immunological category } 1 \\
67(40 \%) \text { immunological category } 2 \\
70(42 \%) \text { immunological category } 3\end{array}$ \\
\hline Routine appointments during the evaluation period & $\begin{array}{l}48(29 \%) \text { patients missed one or more times } 118(71 \%) \\
\text { did not miss }\end{array}$ \\
\hline $\begin{array}{l}\text { Number of times of switched antiretroviral therapy } \\
\text { (ART) after starting treatment }\end{array}$ & $\begin{array}{l}7(4 \%) \text { patients were without ART } \\
99(60 \%) \text { patients switched ART }<5 \text { times } \\
60(36 \%) \text { patients switched ART } \geq 5 \text { times }\end{array}$ \\
\hline $\begin{array}{l}\text { Adherence to ART: consultations recording lack of } \\
\text { adherence }\end{array}$ & $\begin{array}{l}133(80 \%)<3 \text { references } \\
33(20 \%) \geq 3 \text { references }\end{array}$ \\
\hline Coinfection after starting treatment & $\begin{array}{l}26(16 \%) \text { coinfected; } \\
140(84 \%) \text { not coinfected }\end{array}$ \\
\hline $\begin{array}{l}\text { Number of medical specialties, except pediatrics, } \\
\text { during the evaluation period }\end{array}$ & $\begin{array}{l}144(87 \%) \text { patients underwent less than } 3 \text { medical } \\
\text { specialties } \\
22(13 \%) \text { underwent three or more medical specialties }\end{array}$ \\
\hline $\begin{array}{l}\text { Most required specialties during the evaluation } \\
\text { period, except pediatrics }\end{array}$ & $\begin{array}{l}38(23 \%) \text { neurology; } \\
36(22 \%) \text { ophthalmology, } \\
24(14 \%) \text { otolaryngology, } \\
22(13 \%) \text { dermatology } \\
20(12 \%) \text { cardiology }\end{array}$ \\
\hline $\begin{array}{l}\text { Social worker consultation during the evaluation } \\
\text { period. }\end{array}$ & $\begin{array}{l}26(16 \%) \text { patients had consultation } \\
140(84 \%) \text { patients did not have consultation }\end{array}$ \\
\hline \multicolumn{2}{|c|}{$\begin{array}{l}\text { \# Social need level during evaluation period: Patients were classified in "high" level because were references in medical records } \\
\text { of: guardian council, law judge, home support services or child institutionalization, suspected of sexual abuse, drugged clinic. } \\
\text { Patients were classified in the "middle" level because were references to basic health unit, home visit and nongovernmental } \\
\text { organization. Patients were classified in the "lower" level because there was none of the references already cited. }{ }^{\star} \text { CDC - clinical } \\
\text { staging and immunological classification for HIV infection. }\end{array}$} \\
\hline
\end{tabular}

Similarly, the PELC-T score contrasts with systems that perform quality assessment by defining a pattern and comparing processes with the pattern, for example, accreditation systems such as the Joint Commission, certifications systems such as ISO (International Organization for Standardization), and national accreditation programme for hospitals (for example DDKM - Danish Healthcare Quality Programme ${ }^{19}$ ) because the PELC is not restricted to compare the processes with the pattern.

We have observed that seals of quality and their standards mostly attract the attention of health managers and doctors involved in management, whereas professionals working directly in healthcare are drawn to scores representing clinical and physiological aspects of each patient. Because PELC combines both approaches, it helps integrate these two groups of professionals in the efforts for quality improvement.

We observed that the HIV pediatric care quality standard created and used in this study, as the approach of the PELC method, has potential applicability in the practice of everyday health and high attractiveness for physicians directly attached to the patient. Each patient is assessed individually, with the inclusion of design elements, process and results of clinical, social and organizational predictors of a quality goal (set in the research) to the patient care trajectory.

In the HIV pediatric research, the PELC T score distribution presented a range compatible 
with the clinical and social reality of the $166 \mathrm{pa}-$ tients evaluated. Significantly, the fact stands out that one of the patients achieved a PELC T score of 97 points, near the maximum of 100 points, indicating the feasibility of the pediatric HIV care quality standard. Additionally, the value of the $3 \mathrm{rd}$ quartile PELC T score indicates that over 40 patients showed degree of compliance greater than or equal to $75 \%$ of the maximum possible score.

The four epidemiological evidences founded in HIV pediatric research are similar to those found in the literature ${ }^{20-23}$.

On key factors to treatment adherence and attendance to consultation in otolaryngology, several authors indicate that poor adherence to antiretroviral therapy is associated with failure in controlling viral replication, immune deterioration, the risk of resistance to antiretroviral agents, thus becoming major challenge to systems geared to the care of patients with HIV ${ }^{20-22}$.

In our interpretation, the need for consultation in otolaryngology is a marker of disease severity, probably secondary to treatment failure. The prevalence of ENT manifestations in pediatric AIDS, particularly upper respiratory tract infections, is high, ranging in the literature between 50 and $100 \%$, especially during the period prior to the availability of therapy ${ }^{22}$. This challenge is particularly important in a scenario such as Brazil, where the National STD / AIDS, since its creation in 1986, mobilizes significant resources to ensure free and universal access to preventive measures and to antiretroviral therapy, with significant impact on morbidity and pediatric mortality ${ }^{17}$.

Fault factors in routine consultations and social vulnerability are cited by several authors ${ }^{21,23}$. Studies in pediatric cohorts suggest that the inclusion of psychosocial interventions, care gratuity, psychotherapy, information and advice and support in relation to the caregiver are associated with better retention in care and adherence to treatment.

We need to repeat the HIV pediatric research in other health services to see whether the same four factors are quality degree predictors. Identifying a small number of significant key variables associated with the quality level of individual care trajectories has many advantages, among them reducing monitoring costs of programs for specific diseases, and consequently, spending the available funds more rationally. This helps reduce disparities in the degree of conformity among different populations, and advances towards more equity in healthcare.

The mere act of creating and disseminating the care quality standard instrument among doctors, nurses, social assistants and other health professionals already leads to a spontaneous self-assessment of possible omissions or flaws in their current practice. Afterwards, when actual scores of their patients are made available, they are further motivated to improve the quality level of their work. In our HIV pediatric research, many suggestions for interventions arose among them in both these moments.

After the key variables having been identified, doctors use these evidences to decide which interventions should be implemented, and for which groups of patients. Not all interventions need be applied to all patients. Time-consuming actions such as confirming the presence of patients in scheduled appointments, or actions involving additional cost, such as providing transportation for patients, could be implemented only for high risk patients, as indicated by the score.

The PELC method is well aligned with the approach advocated by the WHO, partly inspired in the experience of the aviation industry, which has achieved very high levels of safety through standardization. In particular, PELC addresses the issues of (1) practice standardization; (2) identification of nonconformities, adverse events and near-misses; (3) development and implementation of interventions to increase quality of care and patient safety; and (4) implementation of a long-term quality level monitoring system.

PELC method is quite unique because, aiming to identify key variables and propose interventions for quality level improvement, it scrutinizes factors in organizational, clinical and social realms by epidemiologic and managerial methods. In fact, the method can be regarded as a new research model on disease care guidelines and the resulting individual care trajectories.

After the HIV pediatric research - the first practical PELC application - we came to believe that PELC can actually be used in any kind of care, both for local and multicentric studies involving centres of technological innovation of universities and governments, provided that all parties agree upon a single care quality standard instrument.

As more research is carried out applying the PELC method, a clearer idea of its potentialities and limits will emerge. 


\section{Collaborations}

ER Campos, DC Moreira-Filho and MTN Silva worked on the conception, design, analysis, interpretation of data and approval of the article version to be published.

\section{References}

1. Kohn LT, Corrigan JM, Donaldson MS. To err is human: building a safer health system. Washington: National Academy Press; 2000.

2. Horstmann E, Brown J, Islam F, Buck J, Agins BD. Retaining HIV-infected patients in care: where are we? where do we go from here? Clin Infect Dis 2010; 50(5):752-761.

3. Gawande A. The checklist manifesto: how to get things right. New York: Metropolitan Books; 2009.

4. Chassin MR, Loeb JM, Schmaltz SP, Wachter RM. Accountability measures - using measurement to promote quality improvement. N Engl J Med 2010; 363(7):683-688.

5. Campos ER. Método PELC - Método de planejamento epidemiológico de linha de cuidado [thesis]. Campinas: Unicamp; 2011.

6. Campos ER, Moreira-Filho DC, Silva MTN. Epidemiology and Policy: P1-299 - Method PELC: Method of epidemiologic planning for lines of care. J Epidemiol Community Health 2011; 65(Supl. 1):A149-A150.

7. Ahrens W, Pigeot I. Handbook of epidemiology. Berlin: Springer-Verlaz; 2005.

8. Campbell DT, Stanley JC. Experimental and quasi-experimental designs for research. Boston: Houghton Mifflin Company; 1966.

9. Donabedian A. Evaluating the quality of medical care. Milbank Q 2005; 83(4):691-729.

10. Langley JG, Moen R, Nolan MK, Nolan TW, Norman CL, Provost LP. The improvement guide: a practical approach to enhancing organizational performance. San Francisco: Josey-Bass Publishers; 2009.

11. Brasil. Ministério da Saúde (MS). Diretrizes metodológicas: elaboração de pareceres técnico-científicos. $2^{\mathrm{a}}$ ed. rev. e ampl. Brasília: MS; 2009. [Série A. Normas e Manuais Técnicos]

12. World Health Organization (WHO). World alliance for patient safety. Research for patient safety: better knowledge for safer care. Geneva: WHO; 2008.

13. Donabedian A. The quality of care: how can it be assessed? JAMA 1988; 260(12):1743-1748.

14. Streiner DL, Norman GR. Health measurement scales: $a$ practical guide to their development and use. New York: Oxford University Press; 2001.

15. Perkins AJ, Stump TE, Monahan PO, McHorney CA. Assessment of differential item functioning for demographic comparisons in the MOS SF-36 health survey. Qual Life Res 2006; 15(3):331-348.
16. Brasil. Ministério da Saúde (MS). TARV - Recomendações para terapia antirretroviral em crianças e adolescentes infectados pelo HIV. Brasília: MS; 2009. [Série Manuais no 85].

17. Greco DB. The AIDS epidemic: social, scientific and economical impacts and perspectives. Estudos Avançados 2008; 22(64):73-94.

18. Knaus WA, Wagner DP, Draper EA, Zimmerman JE, Bergner M, Bastos PG, Sirio CA, Murphy DJ, Lotring T, Damiano A, Harrell Junior FE. The APACHE III prognostic system: risk prediction of hospital mortality for critically ill hospitalized adults. Chest 1991; 100(6):1619-1636.

19. Institut for Kvalitet og Akkreditering i S. Den Danske Kvalitetsmodel, Akkrediteringsstandarder for sygehuse, 1. version, 2009

20. Vreeman RC, Wiehe SE, Pearce EC, Nyandiko WM. A systematic review of pediatric adherence to antiretroviral therapy in low- and middle-income countries. Pediatr Infect Dis J 2008; 27(8):686-691.

21. Fetzer BC, Mupenda B, Lusiama J, Kitetele F, Golin C, Behets F. Barriers to and facilitators of adherence to pediatric antiretroviral therapy in a sub-saharan setting: insights from a qualitative study. AIDS Patient Care STDs 2011; 25(10):611-621.

22. Singh A, Georgalas C, Patel N, Papesch M. ENT presentations in children with HIV infection. Clin Otolaryngol Allied Sci 2003; 28(3):240-243.

23. Nachega JB, Millsc EJ, Schechterd M. Antiretroviral therapy adherence and retention in care in middle-income and low-income countries: current status of knowledge and research priorities. Current Opinion in HIV and AIDS 2010; 5(1):70-77.

Artigo apresentado em 17/09/2015

Aprovado em 20/07/2016

Versão final apresentada em 22/07/2016 